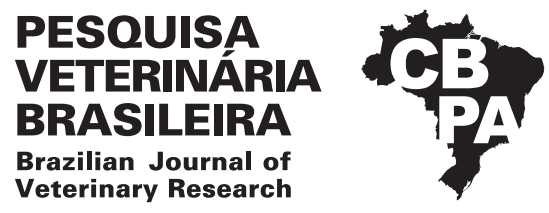

Pesq. Vet. Bras. 38(11):2175-2182, novembro 2018 DOI: 10.1590/1678-5150-PVB-5527

Original Article

ISSN 0100-736X (Print)

ISSN 1678-5150 (Online)

\title{
Subplacental development in Galea spixii ${ }^{1}$
}

\author{
Ferdinando V.F. Bezerra ${ }^{2 *}$, Phelipe O. Favaron ${ }^{3}$, Andrea M. Mess ${ }^{3}$, \\ Hélio N. Araújo Júnior ${ }^{2}$, Gleidson B. Oliveira² ${ }^{2}$, Alexsandra F. Pereira ${ }^{2}$, \\ Maria A. Miglino ${ }^{3}$ and Moacir F. Oliveira ${ }^{2}$
}

\begin{abstract}
Bezerra F.V.F., Favaron P.O., Mess A.M., Araújo Júnior H.N., Oliveira G.B., Pereira A.F., Miglino M.A. \& Oliveira M.F. 2018. Subplacental development in Galea spixii. Pesquisa Veterinária Brasileira 38(11):2175-2182. Universidade Federal Rural do Semi-Árido, Av. Costa e Silva s/n, Mossoró, RN 59625-900, Brazil. E-mail: ferdinando_vinicios@hotmail.com

Animal models are essential to understand healthy human placentation. Guinea pig related rodents became on focus for such purposes. In particular, processes of trophoblast invasion are similar. The latter is associated with a specialized area, the subplacenta. Since previous results showed differences between the guinea pig and its close relative Galea spixii, we aimed to study subplacental development with more detail. We investigated 16 pregnant females of 14 to 55 days of gestation by means of histology, morphometrics, immunohistochemistry and electron microscopy. The overlap between the fetomaternal blood systems resulted as intimate, suggesting some exchange processes. Proliferation was revealed by three independent methods, being most active in early and mid-gestation, which was in accordance to former results. Though degeneration of tissues took place, the subplacenta was maintained towards term with access to the fetal vascularization, supporting a hypothesis about the release of substances to the fetal unit in advanced gestation. In contrast to other species, the extraplacental trophoblast showed a shift from syncytial streamers to giant cells during mid-gestation. Views on placentation in caviomorphs were influenced by the guinea pig, but our data supported recent studies that the subplacenta had a much greater placidity. In regard to subplacental grow, degeneration and likely also exchange processes, Galea and other species showed a more basal pattern of caviomorphs than the guinea pig. Such differences should be considered, when choosing most adequate animal models for special purposes in comparison to human placentation.
\end{abstract}

INDEX TERMS: Placenta, cytotrophoblast, syncytiotrophoblast, trophoblast invasion, guinea pig, Galea spixii, animal model.

RESUMO.- [Desenvolvimento subplacentário do preá (Galea spixii).] Modelos animais são essenciais para entender a placenta humana sadia. Neste sentido os roedores relacionados ao porquinho da índia tornaram-se foco para tal entendimento. Em particular, os processos de invasão trofoblástica são semelhantes. 0 último está associado a uma área especializada, a subplacenta. Uma vez que os resultados anteriores mostraram diferenças entre o porquinho da índia

\footnotetext{
${ }^{1}$ Received on October 26, 2017.

Accepted for publication on November 23, 2017.

${ }^{2}$ Universidade Federal Rural do Semi-Árido (UFERSA), Av. Costa e Silva s/n, Mossoró, RN 59625-900, Brazil.*Corresponding author: ferdinando_vinicios@hotmail.com

${ }^{3}$ Departamento de Cirurgia, Faculdade de Medicina Veterinária, Universidade de São Paulo (USP), Avenida Prof. Dr. Orlando Marques de Paiva 87, Cidade Universitária, São Paulo, SP 05508-000, Brazil.
}

e seu relativo o preá, buscamos estudar o desenvolvimento subplacentário com mais detalhes. Pesquisamos 16 fêmeas gestantes de 14 a 55 dias de gestação por meio de histologia, morfometria, imuno-histoquímica e microscopia eletrônica. A sobreposição entre os sistemas sanguíneos materno e fetal apresentou-se com íntima relação, sugerindo alguns processos de troca. A proliferação foi revelada por três métodos independentes, sendo mais ativos no início e metade da gestação, o que corroborou com os resultados anteriores. Embora a degeneração dos tecidos tenha ocorrido, a subplacenta foi mantida até o termo gestacional com acesso à vascularização fetal, apoiando uma hipótese sobre a liberação de substâncias para a unidade fetal em gestação avançada. Em contraste com outras espécies, o trofoblasto extraplacentário mostrou uma mudança de flâmulas sinciciais para células gigantes durante a metade da gestação. As visualizações sobre a placentação em caviomorfos foram influenciadas pelo porquinho da 
índia, mas nossos dados apoiaram estudos recentes de que a subplacenta apresentava uma plasticidade muito maior. Em relação ao crescimento subplacentário, a degeneração e provavelmente também os processos de troca, o preá e outras espécies apresentaram um padrão mais basal de caviomorfos do que o porquinho da índia. Tais diferenças devem ser consideradas, ao escolher os modelos animais mais adequados para fins especiais em comparação com a placentação humana.

TERMOS DE INDEXAÇ̃̃O: Placenta, citotrofoblasto, sinciciotrofoblasto, invasão trofoblástica, preá, Galea spixii, modelo animal.

\section{INTRODUCTION}

In regard to better understanding healthy pregnancy as well as potential problems in human beings, animal models on placentation are essential (Carter 2007, Carter \& Mess 2014, Mess 2014). Recently the guinea pig and caviomorph rodents in general have been regarded as suitable models for placentation. They share more similarities of placental fine structure and trophoblast invasion with humans than other mammalian taxa such as murids including the mice (Mess et al. 2007, Mess 2014). Moreover, they possess relatively long gestation periods and give birth to well-developed offspring that allows modeling conditions of advanced human pregnancy (Carter \& Mess 2014).

In the last decade placentation was investigated in several caviomorph species (Davies et al. 1961a, 1961b, Kaufmann \& Davidoff 1977, Wolfer \& Kaufmann 1980, Miglino et al. 2002, 2004, Kaufmann 2004, Bonatelli et al. 2005, Oliveira et al. 2006, 2008, Rodrigues et al. 2006, Bosco et al. 2007, Mess 2003, 2007a, 2007b, Mess \& Carter 2007, Mess et al. 2007, Kanashiro et al. 2009, Flamini et al. 2011, Oliveira et al. 2012a, 2012 b) revealing a quite stable pattern of evolution that is largely independent from size diameters or reproductive specializations (Kanashiro et al. 2009, Flamini et al. 2011, Mess 2011, 2014). In particular, trophoblast invasion in caviomorphs is associated with a specialized area within the placental disk, the so-called subplacenta (Kaufmann 2004, Rodrigues et al. 2006, Mess et al. 2007, Mess 2007a, 2011, 2014). It represents an area of folded layers of cellular and syncytial trophoblast, formed at the central excavation in association to the maternal blood system early in gestation, but that is supplied by fetal vessels only in later phases (Fig.1).

It serves as origin and proliferation center for extraplacental trophoblast that migrates into the decidua to destroy and remodel the maternal arteries (Kaufmann 2004, Mess et al.2007, Mess 2007a, 2011). However, there are some differences within the group, especially when comparing the guinea pig with one of its closest relatives, the prea Galea spixii that exhibits the semiarid caatinga vegetation of northeast Brazil (Moojen 1952, Pinheiro et al. 1989, Bonvicino et al. 2008, Oliveira et al. 2008). In the latter, illustrations of subplacental structures focus on early ontogeny until day 12, whereas older stages are only superficially described (Oliveira et al. 2008). Moreover, the length of gestation in the prea is variable and recent data indicated that it is about 55 to 60 days in animals from our breeding facilities (Vale 2011) and not 48 days as was assumed for former placental studies (Oliveira et al. 2008, 2012 b). Thus, real near term conditions of the subplacenta are absent in the literature (Oliveira et al. 2008). To better understand subplacental development throughout gestation in Galea and to compare with already established animal models for human placentation, we investigated placentas of days 14 to 55 by means of histology, morphometric analysis, immunohistochemistry and electron microscopy.

\section{MATERIALS AND METHODS}

Animals and ethics statement. Sixteen females of gestational days $14,15,23,25,30,33,45,50,52,53$ and 55 were investigated, obtained from the Multiplication Center Wild Animals (CEMAS/UFERSA), Mossoro (Register \#1478912 by IBAMA), authorized by the System of Authorization of Biodiversity Information in Brazil (SISBIO \#35231-1). The project was approved by the Ethical Committee (CEUA/UFERSA) (Protocol \#68/2012). For breeding, four groups with four adult females and one male, respectively, have been established. These animals are small rodents, with small ears, devoid of tail and with average weight of $300 \mathrm{~g}$ and that have dorsal gray coloration, with brunáceo tone and white belly and hind legs with three digits. They inhabit the capoeiras, between stones, barriers of rivers and reeds, feeding on grasses and roots and were housed in a $5 \mathrm{~m}^{2}$ area and fed rations for rodents, fruits, soybeans, maize and water ad libitum, so that each group had the same food management. Pregnancy was detected by daily vaginal cytology tests, with the presence of sperm indicating day zero.

Anesthetic surgical procedure. Once the pregnancy was identified, the animals were separated and the day before the collection were subjected to a solid twelve hour fast and a six hour liquid. At the time of collection, the animals were weighed and submitted to anesthetic procedure. For this, the combination of xylazine hydrochloride (Xilazin ${ }^{\circledR} 2 \%$ at the dose of $1 \mathrm{mg}^{\circledR} \mathrm{kg}^{-1}$, manufacturer Syntec) and hydrochloride of ketamine (10\%) was administered intramuscularly, after waiting time $(10 \mathrm{~min})$ the thiopental anesthetic $1 \mathrm{~g}$ (Thiopental sodium $1 \mathrm{~g}$ at the dose of $25 \mathrm{mg} \mathrm{kg}^{-1}$, manufacturer Richmond, Division Veterinaria SA) by intravenous route as an anesthetic-inducing drug. The anesthetic plan was followed by administration of Potassium Chloride (19.1\% potassium chloride at a dose of $2.56 \mathrm{mEq} . \mathrm{kg}^{-1}$, manufacturer Halexistar) also by intravenous route, confirming the death of the animal after cardiorespiratory arrest.

Histology. Tissues for histology were fixed by immersion in buffered $4 \%$ paraformaldehyde after female euthanasia, transferred to decreasing concentrations of alcohol and xylene, embedded in paraffin, cut and then stained with hematoxylin and eosin (HE), Masson's trichrome and the periodic acid-Schiff reaction (PAS) (Oliveira et al. 2008, 2012a, 2012b). Slides were analyzed by a Leica ICC50 HD microscope.

Qualitative proliferation. Was revealed in main stages. In slides photographed at $100 x$ magnification, a total of 1000 cells were counted and the mitotic index was obtained by the relative number of cells with positive signals of mitosis compared to the total number of cells. Also, Argyrophilic Nucleolar Organizer Regions (AgNOR) were calculated in silver-stained slides (Santos et al. 2012). Sections were deparafinized, post-fixed in absolute ethanol and acetic acid (3:1), rehydrated and stained by a $2: 1$ mixture of (a) $2 \%$ unflavored gelatin in aqueous $1 \%$ formic acid and (b) $50 \%$ silver nitrate in water, protected from light. Slides were post-fixed with $5 \%$ sodium thiosulfate, dehydrated, mounted and AgNORs were counted 200 nuclei in each slide and were used 4 slides, randomly chosen, per animal totaling 800 nuclei per animal.

Immunohistochemistry. Was performed for vimentin, cytokeratin and PCNA (Oliveira et al. 2008, 2012b). The material was rehydrated in ethanol and submitted to endogenous peroxidase blockage in $3 \%$ hydrogen peroxide. The sections were treated in $0.1 \mathrm{M}$ citrate 


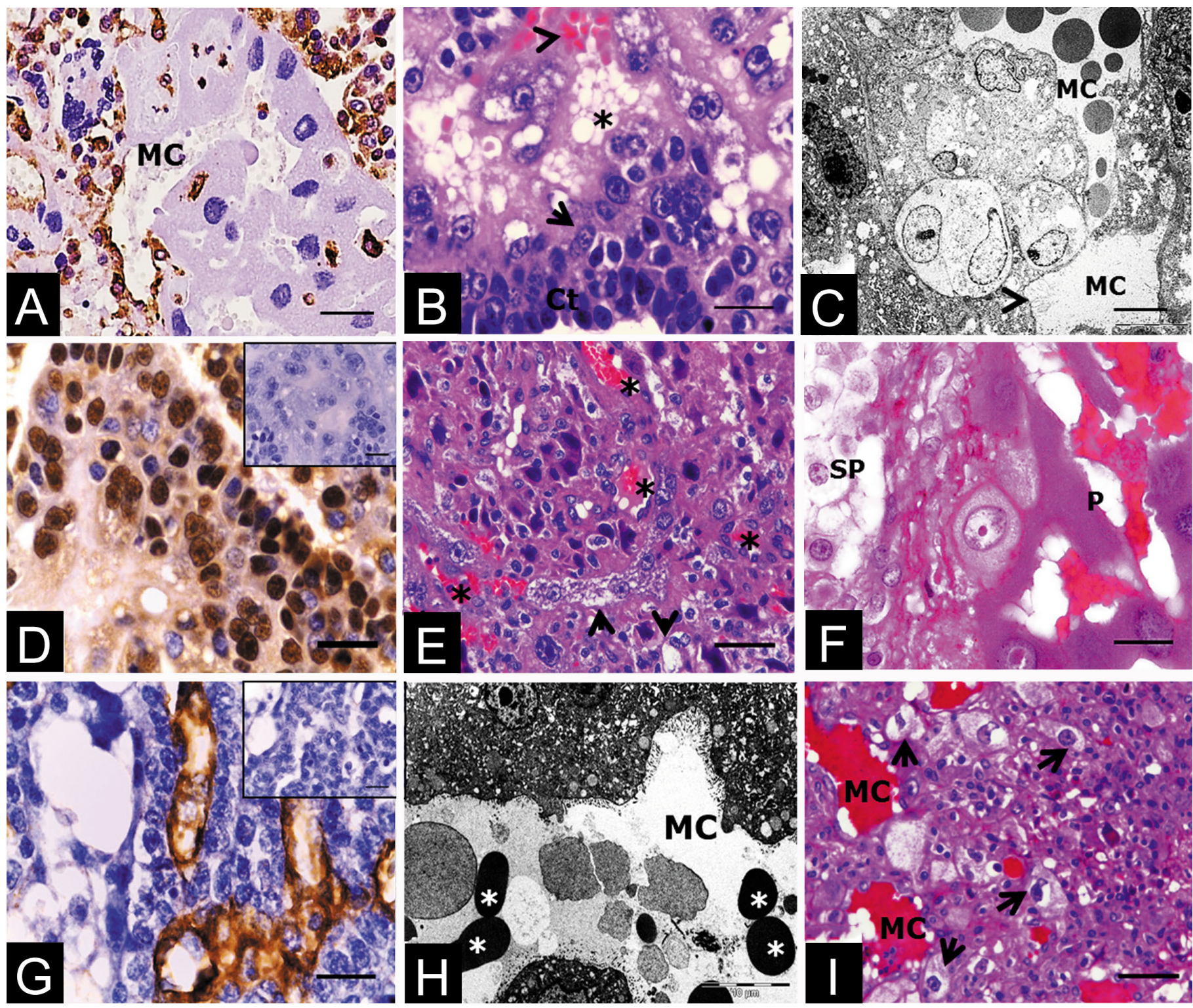

Fig.1. (A-E) Day 15 and (F-I) day 23. (A) The subplacenta was supplied by the maternal arterial system that partly possessed a vimentin-positive endothelium. Vimentin reaction, bar $=20 \mu \mathrm{m}$. (B) An area of cytotrophoblast surrounded by syncytiotrophoblast with lots of vacuoles $\left({ }^{*}\right)$ and associated with maternal blood channels (arrowheads). HE, bar $=20 \mu \mathrm{m}$. (C) Maternal blood channels lined by syncytiotrophoblast. Giant cells occurred in between. TEM, bar $=10 \mu \mathrm{m}$. (D) Cellular trophoblast and giant cells inside the syncytial layer were proliferative. PCNA with negative control, bar $=20 \mu \mathrm{m}$. (E) Syncytial streamers were frequent between the subplacenta and maternal blood vessels of the decidua. HE, bar $=50 \mu \mathrm{m}$. (F) The subplacenta was separated from the main placenta by connective tissue with giant cells situated in-between. HE, bar $=20 \mu \mathrm{m}$. (G) Positive reaction showed fetal vessels that supplied the organ, associated to remnants of maternal blood channels that were lined by vimentin-negative trophoblast. Vimentin and negative control, bar $=20 \mu \mathrm{m}$. $(\mathbf{H})$ Functional maternal blood channel. TEM, bar $=10 \mu \mathrm{m}$. (I) Extraplacental trophoblast included mainly giant cells. HE, bar $=50 \mu \mathrm{m}$.

buffer at pH 7.4, irradiated in a microwave (700MHz), washed in $0.1 \mathrm{M}$ sodium phosphate buffer at $\mathrm{pH} 7.4$ and nonspecific binding was blocked by Dako Protein Block. Then, incubation with the primary antibodies, i.e. polyclonal goat anti-vimentin (SC-1226, Santa Cruz Biotchnology, USA) in dilution 1:400, anti-cytokeratin rabbit polyclonal (PU071-UP, Biogenex) in dilution 1:300 and anti-PCNA monoclonal mice (107 904, Novocastra, UK) in dilution 1:300 too, was done for $12 \mathrm{~h}$ in a humid chamber at $4^{\circ} \mathrm{C}$. Finally, incubation with the peroxidase-conjugated secondary antibody was performed and slides were counterstained with Harris hematoxylin and mounted in Resin-Entellan (Merck, Darmstadt, Germany). Negative controls were performed using goat anti-mouse IgG as the primary antibody solution.

Transmission electron microscopy (TEM). Samples were fixed in buffered $2.5 \%$ glutaraldehyde, post-fixed in osmium tetroxide, embedded in Spurr's Resin and then cut with $0.07 \mu \mathrm{m}$ thickness in an automatic ultramicrotome (Ultracut R, Leica, Germany). Sections were contrasted with $2 \%$ uranyl acetate and $0.5 \%$ lead citrate (Oliveira et al. 2008, 2012a, 2012b) and analyzed in a Morgagni 268D transmission electron microscope (FEI Company, The Netherlands) with a Mega View III camera (Soft Imaging, Germany). 


\section{Days 14 and 15}

\section{RESULTS}

The subplacenta was confluent with the main placenta and had access to the maternal arterial system that in parts still possessed its endothelial lining (Fig.1A). Attached to the folded basal membrane facing the central excavation, cytotrophoblast composed of cubic, mostly multilayered, but partly pseudo-stratified cells occurred (Fig.1B). The cytoplasm was basophil and the nuclei were round with chromatin and scattered clumps (Fig.1B). Above was an extended syncytiotrophoblast with eosinophilic cytoplasm and vacuoles (Fig.1B) that lined the maternal blood channels (Fig.1C). It was positive to PAS. In between, giant cells occurred (Fig.1C). The cellular trophoblast and these giant cells were actively proliferating (Fig.1D). Extraplacental trophoblast was frequent, consisting predominately of syncytial streamers intermingled with some giant cells (Fig.1E).

\section{Days 23 and 25}

The lobulated, highly proliferative subplacenta was confluent to the decidua (Fig.1), but in large parts separated from the main placenta by a thin layer of connective tissue with giant cells being frequent at the border (Fig.1F). Fetal vessels and maternal blood channels were present (Fig.1G,H), but some of the channels were filled with amorphic material. Extraplacental trophoblast primarily included mononucleated giant cells instead of syncytial streamers (Fig.1I).

\section{Days 30 and 33}

The prominent subplacenta is mainly, but not exclusively separated from the main placenta, showing some lateral cell clusters continuing towards the interlobium (Fig.2A). Inside, fetal vessels could be followed in-between the cellular and syncytial areas of the folds (Fig.2B,C). Also, several functional maternal blood channels were present, in parts associated with only thin syncytiotrophoblast (Fig.2D). The proliferation activity of subplacental cells was high (Fig.2E). The extraplacental trophoblast was decreased to only some trophoblast giant cell clusters.

\section{Days 41 and 45}

Syncytiotrophoblast was most prominent, characterized by plenty, very large vacuoles and positive reactions to PAS, indicating a continued accumulation of glycogen or related carbohydrates (Fig.2F,G). Remnants of the maternal blood channels were found with small internal projections to the inside (Fig.2G). The cellular trophoblast was in parts discontinuous and thin (Fig.3H). Mitotic figures were rare and proliferation low (Fig.2I). Signs of degeneration occurred such as the presence of pyknotic nuclei in the syncytiotrophoblast (Fig.2F).

\section{Days 50, 52, 53 and 55}

Though the relative extension of the subplacenta was strongly decreased, the organ was present and supplied by fetal vessels (Fig.3A). However, extended areas of apomorphic structure occurred inside (Fig.3B), in addition to large amounts of connective tissue in-between the cellular trophoblast that also possessed vacuoles now (Fig.3C,D). Nuclei were often disorganized (Fig.3E). The syncytiotrophoblast was PAS-positive and contained positive amorphous material; it was still found near some rests of the former maternal blood system. Severe signs of degeneration and apoptosis occurred. The proliferation activity was very low (Fig.3F), in contrast to areas inside the placental disk (data not shown).

\section{Qualitative data}

The mitotic index revealed an abrupt decrease between days 30 to 45 , revealing that up to 30 days of gestation the proliferative activity of the subplacenta is high and that in the sequence decreases, until becoming minimal at the end of gestation, whereas counting AgNORs suggested a more graduate decrease throughout gestation (Fig.4A,B), considering that the Agnor's technique portrays not only the proliferation but also the metabolism of the cells, revealing that even with the abrupt decrease of ploriferative activity the organ remains functional.

\section{DISCUSSION}

Our findings agree with Conceição et al. (2008) that report the central positioning of the subplacenta in relation to the main placenta and basal decidua in paca and agouti and showed a relatively close overlap between the fetomaternal blood systems inside the subplacenta, continuation of the organ and its supplement by the fetal vasculature towards term and more detailed views in regard to proliferation and extraplacental trophoblast.

The subplacenta historically was regarded as an organ without fetomaternal exchange, mainly based on studies of the guinea pig where the maternal blood system was stopped by coagulation from day 20 on and fully disappeared at least at day 27, in contrast to the fetal system that started around day 26 to 32 (Kaufmann \& Davidoff 1977, Wolfer \& Kaufmann 1980, Kaufmann 2004). However, recent studies showed a short-term overlap in the prea, the degu Octodon degus, the punare Thrichomys aperoides, the capybara Hydrochaeris hydrochaeris as well as paca Cunniculus paca and agouti Dasyprocta leporina (Miglino et al. 2002, 2004, Bonatelli et al. 2005, Bosco et al. 2007, Mess 2007a, Oliveira et al. 2008, 2012a). Here, we argued for an even more intimate overlap, On the contrary, a hemotricorial barrier is observed in Sigmodontinae (Favaron et al. 2011). Maternal blood spaces in Galea were functional throughout mid-gestation until near term, i.e. found largely in parallel with the fetal vasculature. Only near term, they became filled with amorphous material, indicating a non-functional state. Also, the syncytiotrophoblast was partly very thin and fetal vessels had access towards this layer. Since data suggested a relatively long-lasting and close interaction between the two systems, at least some exchange of substances supporting the effective fetomaternal exchange units in the placental disk should no longer be ruled out.

Our findings in the prea were in accordance to former studies that the subplacenta was active and proliferative in early and mid-gestation (Davies et al. 1961a, 1961b, Kaufmann \& Davidoff 1977, Wolfer \& Kaufmann 1980, Kaufmann 2004, Miglino et al. 2002, 2004, Bonatelli et al. 2005, Oliveira et al. 2006, Rodrigues et al. 2006, Bosco et al. 2007, Mess 2003, 2007a, 2007b, 2011, Mess et al. 2007, Mess \& Carter 2007, Oliveira et al. 2008, 2012a, 2012b, Kanashiro et al. 2009, Flamini et al. 2011). Immunostaining for the proliferation marker PCNA and revealing the mitotic index by morphology both resulted in high proliferation early on, followed by an 

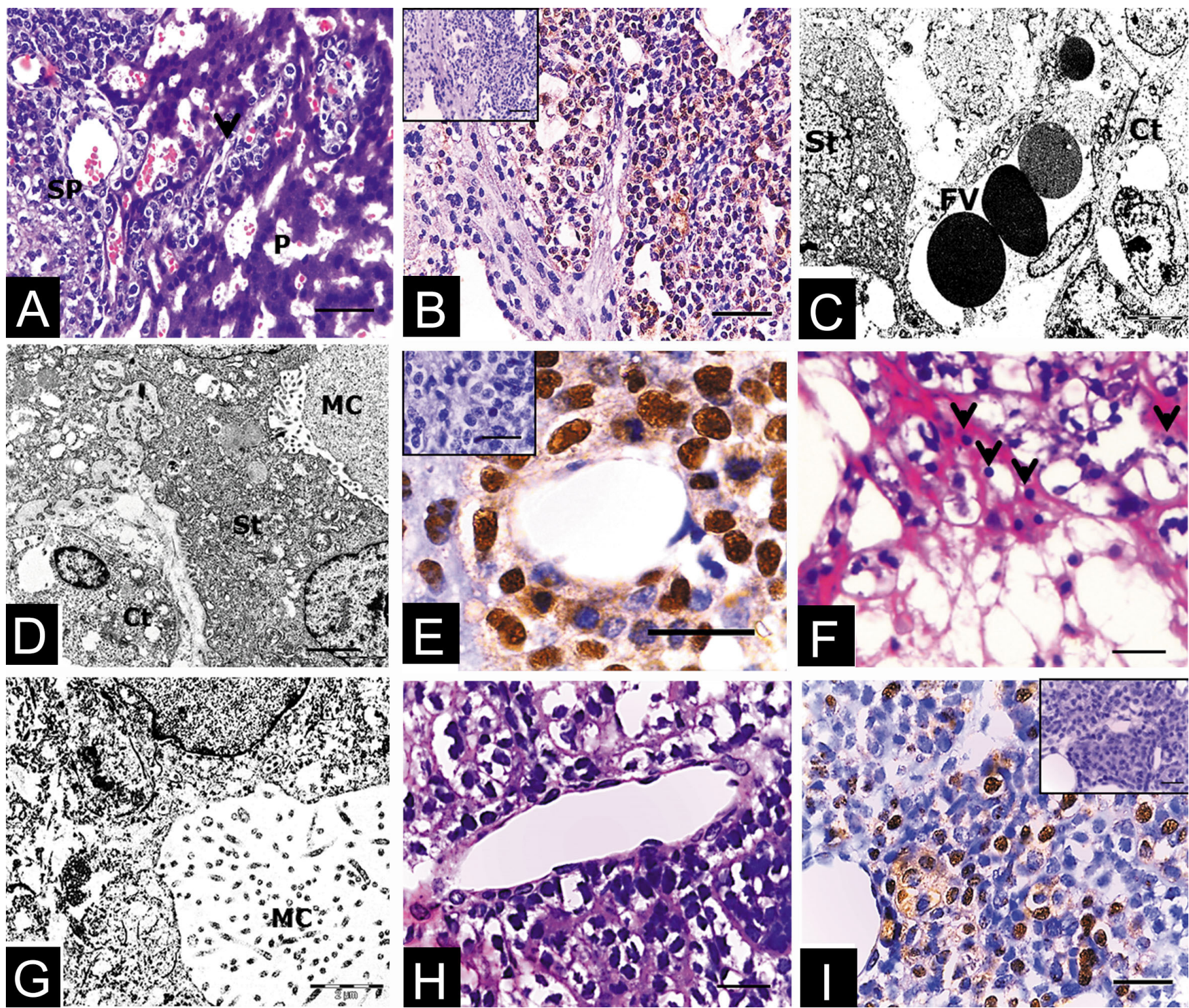

Fig.2. (A-E) Day 30 and (F-I) day 45. (A) Clusters of subplacental trophoblast cells could be followed towards the placental disk. HE, bar $=50 \mu \mathrm{m}$. (B) The endothelium of a fetal vessel was negative, in contrast to (especially cellular) trophoblast. Cytokeration, bar $=50 \mu \mathrm{m}$. (C) Fetal capillary in-between the cellular and syncytial trophoblast. TEM, bar $=5 \mu \mathrm{m}$. (D) In parts, syncytiotrophoblast was very thin near remnants of maternal blood channels. TEM, bar $=5 \mu \mathrm{m}$. (E) Subplacental trophoblast was still very active in proliferation. PCNA, bar $=20 \mu \mathrm{m}$. (F) Syncytiotrophoblast with plenty of large vacuoles and positive reaction. Pyknotic nuclei as signs of degeneration were frequent. PAS, bar $=20 \mu \mathrm{m}$. (G) Rest of a maternal blood channel. TEM, bar $=2 \mu \mathrm{m}$. (H) Cellular trophoblast partly discontinuous and thin. HE, bar $=20 \mu \mathrm{m}$. (I) Rate of proliferation rate was low. PCNA and negative control, bar $=20 \mu \mathrm{m}$.

abrupt decrease around day 45 and further decrease towards term. Calculation of AgNORs focusing on metabolic active nuclei fit into the frame. As to be expected, data showed a more graduate decrease, caused by the inclusion of both pre-mitotic and mitotic stages that lead to a relatively higher number of positive results. For the first time, proliferation processes inside the subplacenta were revealed by three independent methods, supporting the former results. During advanced gestation, the subplacenta generally degenerated (Davies et al. 1961a, 1961b, Kaufmann \& Davidoff 1977, Wolfer \& Kaufmann 1980, Miglino et al. 2002, 2004, Mess 2003, 2007a, 2007b, 2011, Kaufmann 2004, Bonatelli et al. 2005, Oliveira et al. 2006,
2008, 2012a, 2012b, Rodrigues et al. 2006, Bosco et al. 2007, Mess et al. 2007, Mess \& Carter 2007, Kanashiro et al. 2009, Flamini et al. 2011). In addition, these results corroborate with those described in the capybara (Kanashiro et al. 2009) and in the punaré (Oliveira et al. 2012a), however the final phases are not approached in this regard. In the same way, as described by Oliveira et al. (2008), the cytotrophoblast is highly proliferative in the middle third of gestation, which agrees with Davies et al. (1961a, 1961b) who affirm that this is the phase of greater activity, however, it was observed that in prea the phase of greater proliferative and metabolic activity is the initial phase and that from the middle of 

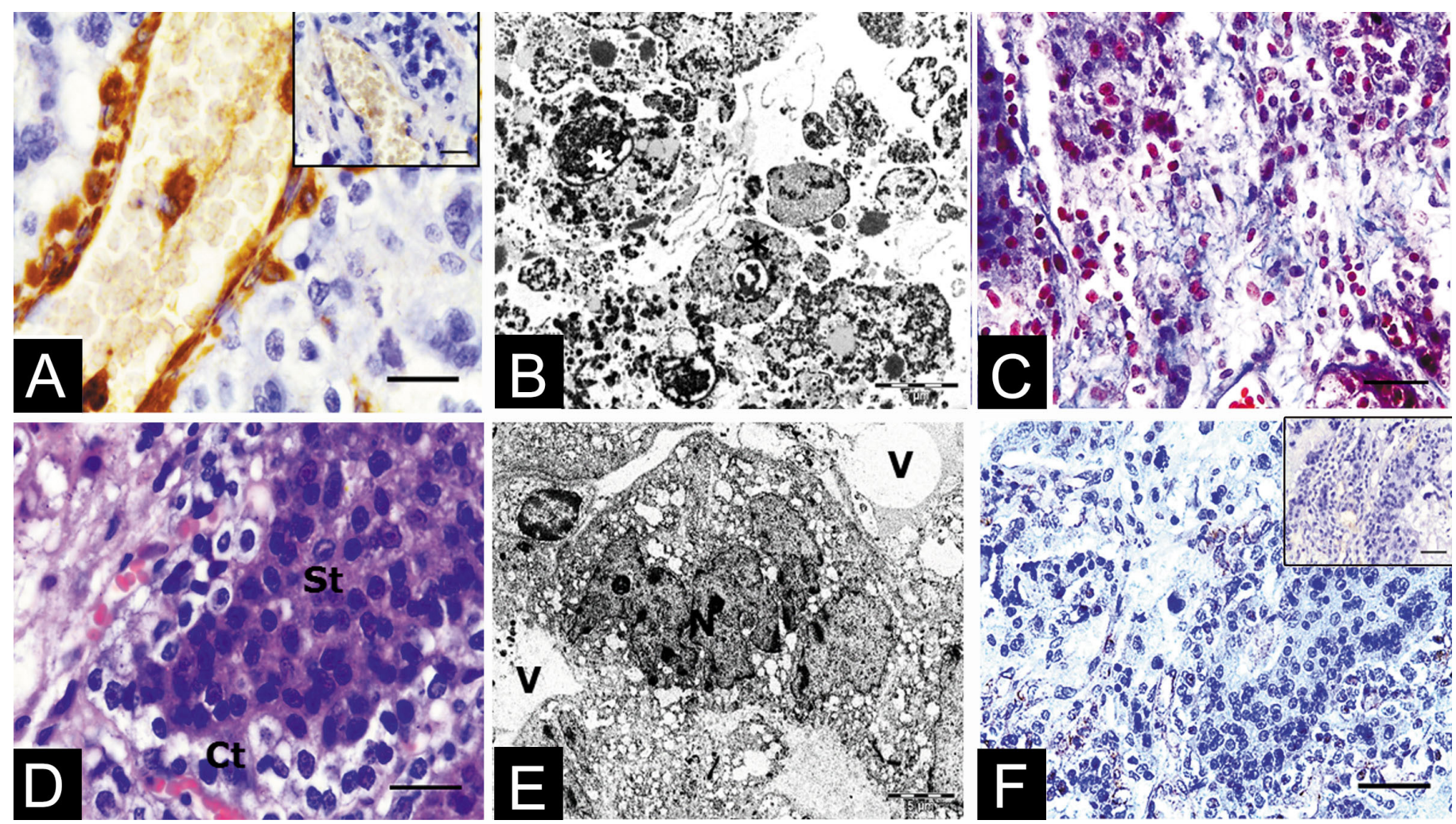

Fig.3. (A) Day 53 to 55. Main fetal vessels supplying the organ. Vimentin and negative control, bar $=20 \mu \mathrm{m}$. (B) Large amorphic areas were present. TEM, bar $=5 \mu \mathrm{m}$. (C) High amounts of connective tissue in-between the cytotrophoblast. Gomori, bar $=50 \mu \mathrm{m}$. (D) Also, cellular trophoblast possessed vacuoles now. HE, bar $=20 \mu \mathrm{m}$. (E) Disorganized nuclei of syncytiotrophoblast. TEM, bar $=5 \mu \mathrm{m}$. (F) Proliferation activity had been stopped. PCNA and negative control, bar $=50 \mu \mathrm{m}$.
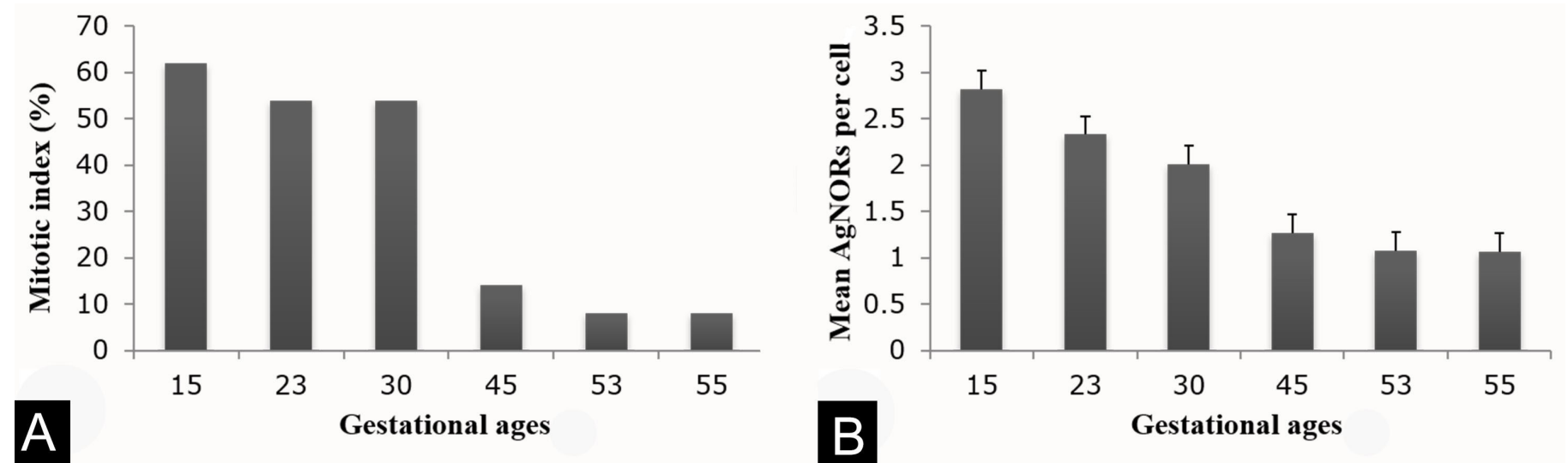

Fig.4. Qualitative proliferative activity. (A) Mitotic index, (B) mean of AgNORs per cell.

gestation both decay. Galea showed the normal pattern with degeneration starting in the syncytiotrophoblast and then affecting the cellular trophoblast. However, a functional state was maintained much longer than in the guinea pig, where the organ was fully resorbed near term (Davies et al. 1961a, 1961b, Kaufmann \& Davidoff 1977, Kaufmann 2004, Mess 2007a, 2011, Mess et al. 2007, Flamini et al. 2011, Carter \& Mess 2014). In contrast, the subplacenta was reduced and filled with amorphous material, but still present and supplied by fetal vessels in the degu, punare, paca, agouti, capybara, and the rock cavy Kerodon rupestris (Miglino et al. 2002, 2004, Bonatelli et al. 2005, Oliveira et al. 2006, 2008, 2012a, 2012b, Rodrigues et al. 2006, Mess 2007a, 2011, Mess et al. 2007, Kanashiro et al. 2009). The here investigated near term stages indicated that Galea belonged to the second group. The positive PAS reaction of the syncytiotrophoblast and the material inside its lacunae, indicating active glycolysation processes associated with secretion, supported a former hypothesis (Rodrigues et al. 2006) that the release of hormones, growth factors or other substances to the fetal unit may be of special 
importance and may also be involved in processes of forthcoming birth. Thus, Galea and other species represented a more basal pattern of caviomorphs than the guinea pig itself, which is also observed in embryos as concluded by Franciolli et al. (2011) studying South American histricomorphic embryos and this variations need to be considered for comparative studies with human placentation as concluded by Miglino et al. (2008).

Finally, a greater placidity in regard to trophoblast invasion was indicated. Whereas in most species both syncytial streamers and giant cells were involved throughout gestation (Kaufmann 2004, Mess 2007a, 2011, Mess et al. 2007, Kanashiro et al. 2009, Flamini et al. 2011), our data suggested that in Galea a shift from syncytial streamers to mononucleated giant cells took place in mid gestation. Further studies are necessary to more fully understand the functional significance and differences of the two types of extraplacental trophoblast.

However, the subplacenta had access to partly intact maternal arteries in early ontogeny and seemed to be involved with the destruction and reorganization of the maternal vessel walls, likewise to what was known from other species of caviomorphs (Kaufmann 2004, Bosco et al. 2007, Mess 2007a, 2011, 2014, Mess et al. 2007, Kanashiro et al. 2009, Flamini et al. 2011, Oliveira et al. 2012a, Carter \& Mess 2014).

\section{CONCLUSIONS}

The subplacental development in the studied species is initially confluent with a main placenta, being initially irrigated by maternal circulation and later replaced by fetal circulation, where both as circulations showed great intimacy without the middle third of gestation.

Its proliferative and metabolic activity are higher in the initial periods of gestation and decay from the middle of gestation, being the most pronounced fall in relation to the proliferation.

Thus, when we observe a subplaced as the center of origin for the trophoblastic invasion and in particular for the intimate relation between the fetal and maternal blood systems during the middle third of gestation, and bearing in mind that there is no ideal model for the human placentation, these are more important in choosing the most suitable model for specifications cases.

Acknowledgements.- We are grateful for technical support to several members of the Universidade de São Paulo, Brazil and the Universidade Federal Rural do Semi-Árido, Mossoró, Brazil. We thank Dr. Andrea Maria Mess for help with the English revision.

Conflict of interest.- The authors declare that they have no competing interests.

\section{REFERENCES}

Bonatelli M., Carter A.M., Machado M.R., Oliveira M.F., Lima M.C. \& Miglino M.A. 2005. Placentation in the paca (Agouti paca L.). Reprod. Biol. Endocrinol. 3(1):1-12. <http://dx.doi.org/10.1186/1477-7827-3-9><PMid:15737234>

Bonvicino C.R., Oliveira J.D. \& D’Andrea P.S. 2008. Guia dos Roedores do Brasil, com Chaves para Gêneros Baseadas em Caracteres Externos. Centro Pan-Americano de Febre Aftosa, Rio de Janeiro. 120p.

Bosco C., Buffet C., Bello M.A., Rodrigo R., Gutierrez M. \& García G. 2007. Placentation in the degu (Octodon degus): Analogies with extrasubplacental trophoblast and human extravillous trophoblast. Comp. Biochem. Physiol. A, Mol. Integr. Physiol. 146(4):475-485. <http://dx.doi.org/10.1016/j. cbpa.2005.12.013><PMid:16448832>
Carter A.M. 2007. Animal models of human placentation: a review. Placenta 28(Suppl.A):S41-S47. <http://dx.doi.org/10.1016/j.placenta.2006.11.002> <PMid:17196252>

Carter A.M. \& Mess A. 2014. Mammalian placentation: implications for animal models, p.2423-2442. In: McManus L.M. \& Mitchell R.N. (Eds), Pathobiology of Human Disease: a dynamic encyclopedia of disease mechanisms. Elsevier, Berlin, Germany.

Conceição R.A., Ambrósio C.E., Martins D.S., Carvalho A.F., Franciolli A.L.R., Machado M.R.F., Oliveira M.F. \& Miglino M.A. 2008. Aspectos morfológicos do saco vitelino em roedores da subordem Hystricomorpha: paca (Agouti paca) e cutia (Dasyprocta agouti). Pesq. Vet. Bras. 28(5):253-259. <http:// dx.doi.org/10.1590/S0100-736X2008000500005>

Davies J., Dempsey E.W. \& Amoroso E.C. 1961a. The subplacenta of the guinea pig: an electron microscopic study. J. Anat. 95:311-324. <PMid:17105123>

Davies J., Dempsey E.W. \& Amoroso E.C. 1961b. The subplacenta of the guinea-pig: development, histology and histochemistry. J. Anat. 95:457473. <PMid:13883829>

Favaron P.O., Carter A.M., Ambrósio C.E., Morini A.C., Mess A.M., Oliveira M.F \& Miglino M.A. 2011. Placentation in Sigmondontinae: a rodent táxon native to South America. Reprod. Biol. Endocrinol. 9(1):55. <http://dx.doi. org/10.1186/1477-7827-9-55><PMid:21518439>

Flamini M.A., Portiansky E.L., Favaron P.O., Martins D.S., Ambrósio C.E., Mess A.M., Miglino M.A. \& Barbeito C.G. 2011. Chorioallantoic and yolk sac placentation in the plains viscacha (Lagostomus maximus) a caviomorph rodent with natural polyovulation. Placenta 32(12):963-968. <http:// dx.doi.org/10.1016/j.placenta.2011.09.002><PMid:21982335>

Franciolli A.L.R., Ambrósio C.E., Oliveira M.F., Morini A.C., Favaron P.O., Machado M.R.F. \& Miglino M.A. 2011. Os histricomorfos sul-americanos: uma análise comparativa do desenvolvimento embriológico. Pesq. Vet. Bras. 31(5):441-446. <http://dx.doi.org/10.1590/S0100-736X2011000500012>

Kanashiro C., Santos T.C., Miglino M.A., Mess A. \& Carter A.M. 2009. Growth and development of the placenta in the capybara (Hydrochaeris hydrochaeris). Reprod. Biol. Endocrinol. 7(1):1-13. <http://dx.doi.org/10.1186/14777827-7-57><PMid:19493333>

Kaufmann P. 2004. Capybara: Hydrochaeris hydrochaeris. In: Benirschke K. (Ed.), Comparative Placentation. Available at <http://placentation.ucsd. edu/capy.htm> Accessed on June 20, 2017.

Kaufmann P. \& David off M. 1977. The guinea pig placenta. Adv. Anat. Embriol. Cell. Biol. 53(2):5-91. <PMid:331890>

Mess A. 2003. Evolutionary transformations of chorioallantoic placental characters in Rodentia with special reference to hystricognath species. J. Exp. Zool. A, Comp. Exp. Biol. 299(1):78-98. <http://dx.doi.org/10.1002/ jez.a.10292><PMid:12950036>

Mess A. 2007a. The subplacenta in Octodon degus and Petromus typicus, two hystricognath rodents without significant placental lobulation. J. Exp. Zool. B, Mol. Dev. Evol. 308B(2):172-188. <http://dx.doi.org/10.1002/ jez.b.21126><PMid:17016808>

Mess A. 2007b. The guinea pig placenta: model of placental growth dynamics. Placenta 28(8/9):812-815. <http://dx.doi.org/10.1016/j. placenta.2007.02.005><PMid:17382996>

Mess A. 2011. Character transformations and their functional significance as a key to the evolution of hystricognath Rodentia. Pesq. Vet. Bras. 31(12):11081115. <http://dx.doi.org/10.1590/S0100-736X2011001200012>

Mess A. 2014. Placental evolution within the supraordinal clades of eutheria with the perspective of alternative animal models for human placentation Adv. Biol. 2014:1-21. <http://dx.doi.org/10.1155/2014/639274>

Mess A. \& Carter A.M. 2007. Evolution of the placenta during the early radiation of placental mammals. Comp. Biochem. Physiol. A, Mol. Integr Physiol. 148(4):769-779.<http://dx.doi.org/10.1016/j.cbpa.2007.01.029> $<$ PMid:17347003> 
Mess A., Zaki N., Kadyrov M., Korr H. \& Kaufmann P. 2007. Caviomorph placentation as a model for trophoblast invasion. Placenta 28(11/12):12341238. <http://dx.doi.org/10.1016/j.placenta.2007.08.003><PMid:17915313>

Miglino M.A., Carter A.M., Ferraz R.H.S. \& Machado M.R.F. 2002. Placentation in the capybara (Hydrochaerus hydrochaeris), agouti (Dasyprocta aguti) and paca (Agouti paca). Placenta 23(5):416-428. <http://dx.doi.org/10.1053/ plac.2002.0806> <PMid:12061858>

Miglino M.A., Franciolli A.L., Oliveira M.F., Ambrósio C.E., Bonatelli M., Machado M.R. \& Mess A. 2008. Development of the inverted visceral yolk sac in three species of caviids (Rodentia, Caviomorpha, Caviidae). Placenta 29(8):748-752. <http://dx.doi.org/10.1016/j.placenta.2008.05.007> <PMid:18586321>

Miglino M.A., Carter A.M., Ambrósio C.E., Bonatelli M., Oliveira M.F., Ferraz R.H.S., Rodrigues R.F. \& Santos T.C. 2004. Vascular organization of the hystricomorph placenta: a comparative study in the agouti, capybara, guinea pig, paca and rock cavy. Placenta 25(5):438-448. <http://dx.doi. org/10.1016/j.placenta.2003.11.002> <PMid:15081638>

Moojen J. 1952. Os Roedores do Brasil. Instituto Nacional do Livro, Ministério da Educação e Saúde, Rio de Janeiro. 214p.

Oliveira M.F., Carter A.M., Bonatelli M., Ambrósio C.E. \& Miglino M.A. 2006. Placentation in the rock cavy, Kerodon rupestris Wied. Placenta 27(1):87-97. <http://dx.doi.org/10.1016/j.placenta.2004.11.012><PMid:16310042>

Oliveira M.F., Mess A., Ambrósio C.E., Dantas C.A., Favaron P.O. \& Miglino M.A. 2008. Chorioallantoic placentation in Galea spixii (Rodentia, Caviomorpha, Caviidae). Reprod. Biol. Endocrinol. 6(1):39. <http://dx.doi. org/10.1186/1477-7827-6-39><PMid:18771596>
Oliveira M.F., Favaron P.O., Ambrósio C.E., Miglino M.A. \& Mess A. 2012a. Chorioallantoic and yolk sac placentation in Thrichomys laurentius (Echimyidae) and the evolution of hystricognath rodents. J. Exp. Zool. B, Mol. Dev. Evol. 318:13-25.

Oliveira M.F., Vale A.M., Favaron P.O., Vasconcelos B.G., Oliveira G.B., Miglino M.A. \& Mess A. 2012b. Development of yolk sac inversion in Galea spixii and Cavia porcellus (Rodentia, Caviidae). Placenta 33(10):878-881. <http:// dx.doi.org/10.1016/j.placenta.2012.06.019><PMid:22809674>.

Pinheiro M.J.P., Andrade S.A. \& Cunha J.N. 1989. Preservação e exploração de animais silvestres: preá, cutia e mocó. Revta Caatinga 6:28-49.

Rodrigues R.F., Carter A.M., Ambrósio C.E., Santos T.C. \& Miglino M.A. 2006. The subplacenta of the red-rumped agouti (Dasyprocta leporina L.). Reprod. Biol. Endocrinol. 4(1):31. <http://dx.doi.org/10.1186/1477-7827-4-31> <PMid:16740154>

Santos T.C., Tonarelli C., Teixeira F.A., Oliveira M.F., Maria D., Reginato P., Kfoury Junior J.R., Oliveira C.A.L., Lourenço D.A.L. \& Miglino M.A. 2012. Histomorphometrical and proliferative aspects of placenta and uterus of the collared peccary (Tayassu tajacu). Histol. Histopathol. 27(6):793-806. <PMid:22473699>

Vale A.M. 2011. Dinâmica da inversão do saco vitelino em preás (Galea spixii Wagler, 1831). Dissertação de Mestrado, Universidade Federal Rural do Semi-Árido, Mossoró, RN. 115p.

Wolfer J. \& Kaufmann P. 1980. Die ultrastruktur der meerschweinchensubplazenta. Anat. Histol. Embryol. 9(1):29-43. <http://dx.doi. org/10.1111/j.1439-0264.1980.tb00838.x> <PMid:6445695> 